For citation: Shkvarya, L. V. \& Frolova, E. D. (2017). Transformations in Socio-Economic Development of the Gulf Group States. Ekonomika regiona [Economy of Region], 13(2), pp. 570-578

doi 10.17059/2017-2-21

JEL: E 27, F 12, F 30

L. V. Shkvarya ${ }^{\text {a) }}$, E. D. Frolova ${ }^{\text {b) }}$

a) Peoples' Friendship University of Russia (Moscow, Russian Federation; e-mail: destard@rambler.ru)

b) Ural Federal University (Ekaterinburg, Russian Federation)

\title{
TRANSFORMATIONS IN SOCIO-ECONOMIC DEVELOPMENT OF THE GULF GROUP STATES ${ }^{1}$
}

The article is devoted to the national economy transformations of the GCC States (Cooperation Council for the Arab States of the Gulf countries). This paper analyzes the dynamics of socio-economic development of the Gulf Group countries for the last 10 years, compares and systematizes the traditional and unique statistical data in order to prove the hypothesis that the positive dynamics was not only due to the high hydrocarbon prices on the global market but also to the successful structural transformation. The growth of the regional economy in the conditions of an almost threefold drop in world oil prices over the past three years is shown. We use systemic approach, comparative and statistical analysis. As the analysis of economic situation and development in the GCC countries at the current stage shows, all of them need to change the structure of the national economy and diversify it in order to reduce the dependence from mining industries, world prices fluctuations. This paper proposes a number of practical considerations and appropriate measures for the formation of more rational structure of the national economies, including the diversification of the sources of budget revenues through expanding industrialization; accelerating development of solid minerals and the creation of new industries using them. As Gulf States belong to the group of emerging countries and the structure of their national economies is similar with the Russian economy, the factors of the positive changes of the national economies will be useful for Russian and foreign researchers.

Keywords: socio-economic system, transformation, national economy, non-oil segment, growth factors, macroeconomic indicators, regional economic growth, GCC, Gulf Group States, West Asia

\section{Introduction}

Arabian Peninsula countries-Bahrain, Qatar, Kuwait, Oman, UAE and Saudi Arabia, members of the Cooperation Council for the Arab States of the Gulf (GCC) since 1998, currently belong to the group of emerging countries engaged in the transformation of national economies on the basis of the new industry segments and diversification.

Many scientists $[1,2]$ mentioned as an accomplished fact the restructuring of the main segments and the national economy in general, which has a deep positive impact on the socio-economic dynamics of the region States. At the same time, as many researchers mentioned, the significant role of the oil and gas sector is stored in the national economies of the Gulf States, that fact confirms the slowdown in macroeconomic indicators of the Gulf States in the years of 2014-2015 [3]. In fact, mentioned and other studies tend to analyze the positive changes that have taken place in the economies of the Gulf States in the 2000s.

In addition, it should be noted that interest in the Gulf States is predefined not only because

1 (c) Shkvarya L. V., Frolova E. D. Text. 2017. of their significant and diverse socio-economic, structural, financial, integration, investment and foreign trade successes, but also because of the Gulf States national economies structure similarity with Russian economy. As well as possible and even necessary intensification of RussianArab economic, trade and investment cooperation, which, in our opinion, could be long-lasting and fruitful for both sides [4]. It is important not only to state, but also to form stable mutual interests but not all countries are interested in mutual development.

The aim of this paper is to add the actual characteristics of the West Asia model development (on the example of Gulf Group States); the tasks are to comprehend and systematize changes which were happened in the region changes in different spheres of socio-economic system, to provide a comprehensive analysis of region transformations, to formulate a number of practical considerations and appropriate measures in order to create a more rational economic structure and ensure long-term and sustainable economic development for this group of countries.

To solve outlined problems we put forward a hypothesis which is that the positive dynamic was 
provided not only due to the high hydrocarbon prices on the global market but also to the successful structural transformation (including the value of non-oil growth factors), that contemporary process of transformation of the GCC States socio-economic structure leads to the complication of the country and regional economic system and reinforces the need to coordinate the development.

Despite the fact that these countries are different in economic, resource and human potential, it is reasonable to study them as a group of countries. According to the Arab scholars' position (for example, A. Barahimi), «the Arab world is a group of countries which are less differentiated from geographical, historical and socio-demographic points of view» than some scientists consider [5].

\section{Literature Review}

There are a lot of modern conceptions of national development with different points of view and trends of the investigation. We have divided all proposals into two groups. The first group consists of theories of economic integration. Modern economists in the Arab world, for example A. Heikal [6], investigate ways to strengthen national economies in the conditions of the strengthening inter-Arab economic integration. But they criticize Western theories, including B. Balassa's one [7]. Since the 1960s to the present time in Arabic scientific school, their own approaches to the interpretation of economic integration are being developed because the Gulf countries are close in their specialization, their economies are not mutually complementary as required by the classical theory of the international economic integration [7]. For example, the Arabic expert A. Barahimi believes that Gulf countries have more prerequisites for a specific integration than opposing factors [5]. This model of integration provides the development of both the "trade" integration and also the «production» one which promotes the formation of the new economic structures at the national and regional levels and development of the strategy of the non-oil specialization. Another Arabic expert Dr. Khalid Shams Abdulqader [8] focuses on the barriers and restrictions in the integration process in the GCC, among which highlights poor private sector contribution to GDP; lack of sophisticated transport network; thwart treaties; some states incapable of integration standards.

The second group consists of the specific concepts of the scientists. For, example, professor I. Aidrous exploring the development of Islamic finance in the region, noted their strategic importance for the national economies, especially for
Bahrain, primarily from the point of diversification of financial flows in the terms of a reduction [9]. M. Isaev notes significant progress in the development of innovative component of the Gulf States economy. At the same time, he concludes that in order «to solve the basic problems of regional development-economic growth accelerating-it is necessary to implement major reforms in the GCC States and in other countries of the region with the purpose to create a more favorable investment climate for regional and foreign investors»10]. R. Cherif devotes his research to the qualitative changes in the commodity structure of export, based on the theory of the international trade [11].

While studying the investment climate in the Arab States, an expert in the field of Gulf Sates foreign investments V. Rusakovich registered the huge positive changes that have emerged in the 2000s as a result of a reasonable liberalization of investment sector, which could be an example for other States. As a result, the increase in foreign investments promoted an employment growth, including among GCC States residents. In addition, V. Rusakovich points that the GCC countries have the potential to significantly increase their position in the international capital migration processes $[12,13,14,15]$. M. Hvidt promotes the theory of a quantum leap through the modernization of the national economies and reforms of the system of economic relations [16].

\section{Data and Methods}

As the main research methods, we applied statistical data analysis in the field of development of national economies of GCC countries and their economic structures, the analysis of the regional experience of the national economic system transformation. At the same time, we use the tools of comparative and content analysis (of the national development Programs and Strategies). We use the UNCTAD statistical database. We have chosen a ten-year period of the research because it allows us to avoid the influence of conjuncture factors.

Assessment of the socio-economic development level of the GCC countries was conducted by statistical analysis of the main macroeconomic indicators that characterize dynamic processes in the region and in individual countries and their comparison within the region and the global economic system with the aim of identifying existing features. At the first stage, we analyze the GDP and GDP per capita dynamics, at the second one-GDP structure of the GCC States and in the world economy. Then we analyze such indicators as GDP sectoral structure. At the final stage, we analyze the 
activities of industrial companies on the basis of case-study

\section{Arab Gulf Countries Development Model: Stable Growth or not?}

In this part of the paper, we will perform analysis according to the above-mentioned stages.

Stage 1. The most important factor determining the socio-economic dynamics of the State is GDP. The dynamics of the Gulf States GDP is presented in Fig. 1.

As we can see from the presented data analysis:

- the GDP dynamics of the Gulf States is fully in trend with global trends and is largely influenced by external factors;

- the rate of regional economic growth is significantly above the world average; from the analysis of the data presented, in value terms total GDP of the region grew in 2006-2015 more than two times (population -1.6 times); at the same time the global economy grew by 51.2 to c 74,75 bln. USD (less than $46 \%$ );

- in 2015, the combined GDP of the GCC countries showed an increase from 1.6 billion (2014) to $\$ 1.7$ billion, i.e. $6.25 \%$. (excluding Kuwait); at the same time the world GDP declined from 78,0 to 74,75 billion, i.e. it decreased by $4 \%$;

- the highest rate of GDP growth will remain in Qatar and the UAE and Saudi Arabia. We can talk about region States economic growth rates equalization in the medium term. According to the IMF estimates (forecasts), the GDP reduction in the Gulf States may have double-digit values. The reason for this situation is the oil prices which continue to remain low on the global market.
Thus, the obtained results contradict to the traditional view that the growth of the economies of the GCC is exactly based on the oil component. On the one hand, indeed, over the past decades, the vector of the economic development of the GCC is tightly correlated with the dynamics of the hydrocarbons world market. On the other hand, in 2014-2016 almost the three-fold drop in oil prices on the world market did not change the direction of the regional economy development: it continued to grow while the world economy declined.

At the stage 2, we examine the quality of the development by means of the GDP per capita analysis (table 1).

Table 1 shows a steady growth of per capita income indicator, which was also negatively affected by the global financial and economic crisis in the years of 2008-2009. At the same time, as it is evident from the presented data analysis, it varies from $\$ 18.8$ thousand in Oman and $\$ 25.2$ thousand in Saudi Arabia to $\$ 55$ thousand in Kuwait and $\$ 100.1$ thousand in Qatar and \$ 46.8 thousand in the United Arab Emirates ${ }^{1}$. The last two digits are the highest in the Arab world in general and Qatar takes on this indicator the 1st place in the world. Also, there has been some slowdown in per capita GDP growth in this group of countries in 2015 related, in our opinion, mainly to the high population growth rates, but not with external factors.

As we can see from the presented data analysis:

- per capita income in the Gulf countries is different;

${ }^{1}$ World Bank. Retrieved from: http://data.worldbank.org/indicator/NE.GDI.TOTL.ZS (date of access: 16.12.2016).

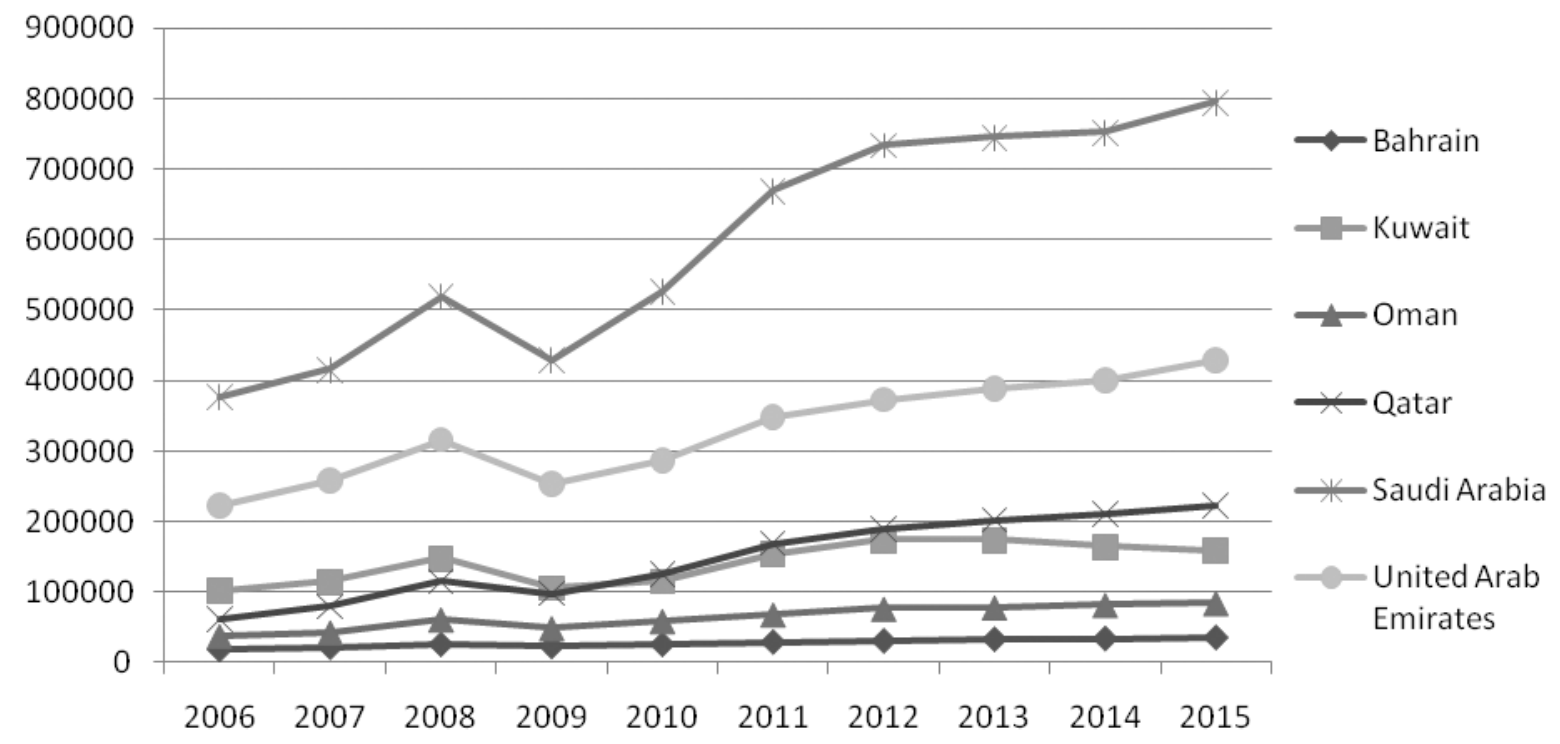

Fig. 1. Gulf countries GDP dynamics in the years of 2006-2015, in current prices mln. USD. 
GDP per capita dynamics of the GCC States in the years of 2006-2015, thousand USD (fragment)

\begin{tabular}{|l|c|c|c|c|c|c|c|c|}
\hline & $\mathbf{2 0 0 6}$ & $\mathbf{2 0 0 7}$ & $\mathbf{2 0 0 8}$ & $\ldots$ & $\mathbf{2 0 1 2}$ & $\mathbf{2 0 1 3}$ & $\mathbf{2 0 1 4}$ & $\mathbf{2 0 1 5}$ \\
\hline Bahrain & 19,5 & 21,05 & 23,04 & $\ldots$ & 23,3 & 24,7 & 25,2 & 25,7 \\
\hline Kuwait & 42,0 & 44,9 & 54,5 & $\ldots$ & 53, & 52,2 & 49,6 & 40,8 \\
\hline Oman & 14,6 & 16,4 & 23,5 & $\ldots$ & 23,4 & 21, & 20,6 & 18,8 \\
\hline Qatar & 62,9 & 69,2 & 84,8 & $\ldots$ & 92,63 & 93,4 & 92,1 & 100,1 \\
\hline Saudi Arabia & 14,9 & 16,05 & 19,7 & $\ldots$ & 25,9 & 25,96 & 25,8 & 25,2 \\
\hline United Arab Emirates & 45,5 & 44,5 & 46,4 & $\ldots$ & 40,4 & 43,05 & 42,9 & 46,8 \\
\hline
\end{tabular}

Source: compiled by the authors according to the United nations conference on trade and development, Statistics. Retrieved from: http://unctadstat.unctad.org (date of access: 16.12.2016).

Table 2

GDP component structure of the GCC States and in the world economy in the years of 2006-2014, $\%$ to GDP (fragment)

\begin{tabular}{|c|c|c|c|c|c|c|c|c|}
\hline $\begin{array}{c}\text { The level of } \\
\text { countries' group }\end{array}$ & Indicator (component) & 2006 & 2007 & 2008 & $\cdots$ & 2012 & 2013 & 2014 \\
\hline \multirow{4}{*}{ World } & $\begin{array}{l}\text { Gross domestic product } \\
\text { (GDP) / Total value added }\end{array}$ & 100 & 100 & 100 & & 100 & 100 & 100 \\
\hline & $\begin{array}{l}\text { Agriculture, hunting, } \\
\text { forestry, fishing }\end{array}$ & 3.4 & 3.6 & 3.8 & & 4.3 & 4.5 & 4.5 \\
\hline & Industry & 29.3 & 29.4 & 29.9 & & 29.9 & 29.7 & 29.5 \\
\hline & Services & 67.3 & 67.1 & $66 / 4$ & & $65 / 7$ & $65 / 8$ & $66 / 0$ \\
\hline \multirow{4}{*}{ GCC } & $\begin{array}{l}\text { Gross domestic product } \\
\text { (GDP) / Total value added }\end{array}$ & 100 & 100 & 100 & & 100 & 100 & 100 \\
\hline & $\begin{array}{c}\text { Agriculture, hunting, } \\
\text { forestry, fishing }\end{array}$ & 1.7 & 1.6 & 1.3 & & 1.1 & 1.1 & 1.1 \\
\hline & Industry & 60.7 & 59.2 & 63.5 & & 62.8 & 60.4 & 57.6 \\
\hline & Services & 37.6 & 39.2 & 35.2 & & 36.1 & 38.5 & 41.3 \\
\hline
\end{tabular}

Source: compiled by the authors according to the United Nations Conference on Trade and Development, Statistics. Retrieved from: http://unctadstat.unctad.org (date of access: 16.12.2016).

- because of the world average GDP per capita indicator was 10,173 тыс. USD in 2015 it means that Gulf countries indicator is significantly above the world average one (for Qatar it is 10 times).

Experience has shown that Arab Gulf countries development model allowed them to increase significantly the effectiveness of their national economies due to the inclusion in the world economy originally through oil exports (with the help of «petrodollars»), and then-through the connection to the global financial system. This has allowed them to ensure a high income per capita.

Therefore, we can conclude that additional sources of the growth have appeared in the region at present. We can identify them based on the analysis of the component structure of the GDP of the GCC countries.

The stage 3 is devoted to the analysis of transformation processes on the basis of the sectoral structure data of the national economy of the GCC countries (table 2).

As we can see from the presented data analysis:

- the share of the industry in the GDP has decreased but the share of services has increased.
The share of agriculture has remained unchanged. At the same time, the comparison with world development indicators shows that the share of industry in the GDP of the GCC is significantly above the world average;

- within the «industry» group, we note the increasing share of refining industry from $8 \%$ of the GDP(up to) to $10 \%{ }^{1}$.

Stage 4. According to the GCC economies structure analysis (Table 3) we can understand the followings:

- consumption expenditure increased slightly mainly due to the growth of the government's spending. In turn, these costs increased due to the financing of programs on development of the green economy, research and educational components;

- on a relative basis (as \% to GDP) consumption expenditure of households decreased from $41.9 \%$ in 2003 to $32.2 \%$ in 2014 , in other words 1.3 times less.

1 Calculated by the authors according to United Nations Conference on Trade and Development, Statistics. Retrieved from: http://unctadstat.unctad.org (date of access: 16.12.2016). 
Table 3

GDP structure of the GCC States in the years of 2006-2014, \% to GDP

\begin{tabular}{|l|c|c|c|c|c|c|c|}
\hline & $\mathbf{2 0 0 6}$ & $\mathbf{2 0 0 7}$ & $\mathbf{2 0 0 8}$ & $\mathbf{\ldots}$ & $\mathbf{2 0 1 2}$ & $\mathbf{2 0 1 3}$ & $\mathbf{2 0 1 4}$ \\
\hline GDP & 100 & 100 & 100 & & 100 & 100 & 100 \\
\hline Final consumption expenditure & 50.38 & 51.62 & 48.25 & & 46.33 & 48.52 & 52.4 \\
\hline Consumption expenditure of households & 34.56 & 36.85 & 35.32 & & 30.92 & 31.93 & 33.2 \\
\hline General government final consumption expenditure & 15.82 & 14.77 & 12.92 & & 15.41 & 16.59 & 19.2 \\
\hline Gross capital formation & 22.31 & 27.36 & 27.12 & & 23.93 & 24.69 & 25.4 \\
\hline Goods and services Export & 63.55 & 64.14 & 67.34 & & 70.21 & 69.12 & 52.4 \\
\hline Goods and services Import & 36.23 & 43.12 & 42.71 & & 40.47 & 42.32 & 33.2 \\
\hline
\end{tabular}

Source: calculated by the authors according to the data UNCTAD, Statistics. Retrieved from: http://unctadstat.unctad.org/wds/ TableViewer/tableView.aspx (date of access: 16.12.2016).

But the most noticeable changes in the GDP structure of the GCC countries relate to gross capital formation, which increased substantially. This growth occurred in terms of value-from \$92.6 trillion in 2003 to $\$ 418.1$ trillion in 2014 , that is 5.7 times. This trend is fully consistent with the fundamental psychological law of John Maynard Keynes: the richer individuals, the greater share of income they save and the smaller share of income they consume. Against the GDP gross capital formation increased during the analyzed period from $20.8 \%$ to $25.4 \%$, (in other words more than $1 / 4$ of total regional GDP), which corresponds to the global gross capital formation level (24.97\%). At the same time, there is a significant differentiation by countries. Gross capital formation value varies (according to the UNCTAD data, in 2014) from $16 \%$ in Bahrain, $24 \%$ in the UAE, $28 \%$ in Saudi Arabia and Oman, $29 \%$ in Kuwait and 32 \% in Qatar.

It is important to note that, as follows from Table 4 statistics analysis, the basic part in the structure of GCC countries gross capital formation accounted for fixed capital. In 2003, the share of fixed capital formation in gross capital formation was $94.6 \%$ in terms of value, and in 2014 it became $92.2 \%$. At the same time, the share of gross fixed capital formation in GDP has increased from $19.78 \%$ to $22.76 \%$ that indicates the presence of positive trends in the regional economy and the base formation for further long-term development. Along with it, the gross fixed capital formation level is somewhat lower than the global rate (24\%), therefore, it is important for GCC countries to continue the existing trend.

This component of the national GDP of the GCC countries enables them to develop not only the traditional hydrocarbon industry, but today, for example, petrochemicals, and the automobile industry.

The region has developed various models of economic development, which are largely influenced by the traditions and beliefs of the Muslim society, including:
- each monarchy, despite the prevailing alliances has substantial specificity;

- with their different growth rate, the most advanced frontier in the socio-economic and state-legal spheres is Kuwait, which had an accelerated development long before its partners;

- the role of the religious factor as a system component is most pronounced in the Saudi kingdom, which hinders advancement into a wide range of social and political scope;

- the economic backwardness of Oman is largely predetermined by the slow destruction of its tribal infrastructures;

- the economic structure of GCC countries is known to have, though in varying degrees, a multi-structural economy, the traditional forms of ownership and public institutions, and an undeveloped market infrastructure;

- along with the modern large-scale manufacturing industry that is widespread in the city, there is also small-scale artisan production in the countryside: there is small and medium business growing there, but which are not a real engine of economic growth.

Stage 5. The content analysis of the Programs and Strategies of the Gulf countries development allows us to identify the measures that contributed to the transformation of their national economies. In the 2000s, all the Gulf countries developed the national long-term strategies of the socio-economic development: Bahrain Economic Vision-2030; UAE Economic Vision-2021; Kuwait Vision-2035; Qatar National Vision - 2030; Oman Economic Vision - 2020. All these strategies aim at the diversification of the economy, development of the human resources, improvement of the efficiency and competitiveness of the private sector. The most significant and important of them are the following ${ }^{1}$.

\footnotetext{
${ }^{1}$ Bahrain Economic Vision - 2030. Retrieved from: http:// www.evisa.gov.bh/Vision2030Englishlowresolution.pdf (date of access: 16.02.2017); Qatar National Development Strategy 2011-2016. Retrieved from: http://www.mdps.gov.qa/en/nds/
} 
1. According to the "UAE Economic Vision-2021" this country aspires to be among the best countries in the world by 2021. The document highlights "we want the UAE to transform its economy into a model where growth is driven by knowledge and innovation". Among important directions for the future development there are: investments in science, technology and research; intellectual property protection; world-class information and communication infrastructure development, services sector development, etc.

2. According to the "Bahrain Economic Vision2030", the goal of the national economy development is to transfer from oil-oriented national economy to competitive one on the base of the high technologies and private innovative sector.

3 . The important document of the Saudi Arabia is "The National Plan for Science, Technology and Innovation, NPSTI 2010-2025" as a part of the Development Program. According to this Plan the country aims to be the leader among the countries in the field of innovations, science, technologies by 2020 . As for industries we would like to name the Saudi Arabian Business Innovation Research program.

It is necessary to add the following information:

- all programs of the innovation development of the Gulf countries suppose to subside government financial recourses, including $2.8 \%$ of the GDP (Qatar), $2 \%$ of the GDP (Saudi Arabia) in 2015-2017;

- the law about foreign investment supposes such measures as corporate tax decreasing from $35 \%$ up to $10 \%$ (Qatar) or tariff preferences for the foreign direct investment (Saudi Arabia) ${ }^{1}$.

Stage 6. The case-study method let us find the effective tools and institutions for the national economy development and competitiveness improvement. As for GCC, first of all, it is the Free Economic Zone (FEZ). Among them, there are Rusayl, Salalah, Sohar, Sur, Nizwa and Buraimi (Oman), Dubai Cars \& Automotive Zone ${ }^{2}$ (UAE), Jebel Ali Free Zone (JAFZA) ${ }^{3}$, etc.

Documents/Qatar_NDS_reprint_complete_lowres_16May. pdf (date of access: 16.02.2017); The national strategy and the e-Government action plan. Retrieved from: http://www.yesser. gov.sa/en/MechanismsandRegulations/strategy/Pages/default. aspx (date of access: 16.02.2017).

1 Global Investment House: Kuwait-Saudi Economic and Strategic Outlook-Foreign Investment-March 2008. Retrieved from: http://www.menareport.com (date of access: 16.02.2017).

2 Dubai Auto Zone. Retrieved from: http://www.uaefreezones. com/fz_dubai_auto_zone.html (date of access: 16.02.2017)

${ }^{3}$ Jebel Ali Free Zone Authority. Retrieved from: http://www. uaefreezones.com/fz_jebel_ali.html (date of access: 16.02.2017).
Also, it is the integration into the global network structures (internationalized reproduction processes). We have designed the sequence of the national structures integration into the global network structure on the example of the Bahrain automobile industry (Mohammed Jalal \& Sons WLL ${ }^{4}$ и Al-Haddad Motors ${ }^{5}$, Ruf Automobile and have received such algorithm: make the general distributor's agreement, firstly in Bahrain and than in the other Gulf countries; creation of the machinery industry cluster; creation of assembly lines (assembling machines using imported components); production of components, spare parts and accessories; car production with the focus on the national and regional market and further to the West Asia market; make the franchise agreement; establishment of the joint ventures; forming of the marketing database; organization of the full-value after-sales service; development of the partnership relations in the field of $R \& D$ and industrial expertise.

In addition to the industry transformation, the above analysis shows a steady growth in the service sector (retail, tourism, logistic, business services, etc.). The financial services sector is the basis of the GCC' national economies today. For example, the Dubai International Financial Centre ${ }^{6}$ specializes in the providing a full range of the financial services, Bahrain International Investment Park ${ }^{7}$ positions itself as the attractive for investments due to tax-free; Qatar Financial Centre (QFC) was established for the international financial organizations' attraction.

\section{Results: Transformations Implemented in GCC Countries}

Below we have described the most significant reformations of the Arab countries in the last decade. So we can formulate some of their results.

1. Expanding the scope of private enterprise demanded the liberalization of economic relations. This is reflected in the recommendations and proposals of the IMF on a possible separation of activities of public and private sectors. In general, there has been an objectively intensified need

\footnotetext{
${ }^{4}$ Mohammed Jalal \& Sons WLL. Retrieved from: https://www. jalal.com/our-business/oil-and-gas/mohammed-jalal-sons-engineering-technology-division (date of access: 16.02.2017).

${ }^{5} \mathrm{Al}$ Haddad Motors. Retrieved from: http://mercedesbenzme. com/bahrain/en/footer/about-us/company-overview/ (date of access: 16.02.2017).

${ }^{6}$ Dubai International Financial Centre. Retrieved from: https:// www.difc.ae (date of access: 16.02.2017).

${ }^{7}$ Bahrain International Investment Park. Retrieved from: http:// www.biip.com.bh (date of access: 16.02.2017).
} 
to move from a predominantly direct to an indirect method of state regulation of the economy.

2. Development of the economy in 19802000. This period was characterized by structural changes in the economy caused by high growth rates of manufacturing industries and services in developed countries of the region. For example, in the UAE the annual average production growth in non-oil sectors of the economy in the period 19902002 amounted to about $8 \%$ against an average of $3.6 \%$ in 1980 . The highest growth rates are observed in the services sector, especially in banking, insurance and tourism, as well as in retail. As a result of structural changes in the economy, the economy of countries in the recent past that were based solely on the oil and gas sector (over $60 \%$ of GDP), are now depending on the non-oil industries and the service sector, whose share in the individual countries of the region reach up to $70 \%$ of GDP [17, p.152].

3. One of the important factors of structural changes in the economy - the growth of domestic consumer demand due to rising incomes and purchasing power of the population, i.e., growth of the internal-Arabian regional market. In the period of 1985-2002, the purchasing power of the population of the UAE, for example, increased by $66 \%$, while the population over this period increased by $150 \%$. At the same time, investing in the non-oil and service sectors in the period 1995-2001 averaged over $25 \%$ of GDP [18].

4. A significant impulse to the region's economies growth and to the restructuring of economic structure gave the development of free economic zones and revitalization of the inflow of foreign business and banking capital ${ }^{1}$, including, probably, Russian. Nowadays FEZ exists in all Gulf States. Their activity is largely a result of the trend towards liberalization of national economies and globalization of the world economy, and is also the object of attention of researchers due to progress in the development and high efficiency of the FEZ, especially in the UAE [19, p. 48-54]. FEZ in the Gulf States, as well as in other countries of the world, contribute to the technology transfer system development, to the influx of innovation, experience and knowledge [20,21], which are strategic important for the sustainable development of the region.

5. A convincing manifestation of modernization in the Gulf countries is a gradual diversification and exports expansion of goods and services

\footnotetext{
${ }^{1}$ Statistical abstract of the ESCWA region. (2001). Economic and social commission for Western Asia. New York: United Nations, 21st issue - XIV, 10-16.
}

of this group of countries, including - high-valueadded products. Also of note is the geographical diversification of foreign trade, including - an increase in the share of turnover such countries as China, India and others [12].

6 . There is a need to transfer the role of the driving force of economic development from the state to the private sector. It is well known that it is private companies, including small and medium size, who are the most efficient due to the flexibility, rapid adaptability to changing market conditions.

7. The regional economic integration, according to the theory and international practice, promoting sustainable socio-economic growth in the integrating countries. Speaking about the Gulf countries, the formation of the Cooperation Council for the Arab States of the Gulf in 1981, almost immediately had a positive impact on the regional economy. At present days, the region formed a customs union with the free movement of goods, capital and labor force. A single external tariff is $5 \%$ of the goods value. In addition, the citizens of the Gulf States have an opportunity to do business in any host country of the region as a resident, including the ability to obtain bank loans etc.

It is typical for most of the GCC countries to take an active part in the economy (including the regulation of its relationship with business, and the expansion of social programs) through a system of economy and public sector regulation by the state that does not alter market mechanisms. In many countries of the region, the public sector was formed even before the national liberation revolutions (Egypt, Iraq, etc.). In Syria, until its independence in 1946, the public sector did not exist. In the 1970s, at the expense of the public sector of the country, they were able to dramatically increase their allocation for economic development. Significant disparities in levels of investment, along with other factors, led to the different rates of economic development in oil and nonoil countries. The presence of favorable conditions for agriculture, advantageous geographical location, etc. still cannot fully compensate for the lack of fuel and energy base, especially oil.

The most important feature of the economic evolution in the region is the introduction of a planning principle for economic development. The idea of «planned development» is used as a concept of economic recovery in this group of states and it rests on the public sector. All Arab states are exploiting programs of economic development, which in one way or another seek to raise the level of production, to develop the basic sec- 
tors of the economy and reduce its dependence on foreign markets. Analysis of these programs shows that despite all the differences in their methods, content and timing, as a rule, a goal to increase the amount of savings, to modernize and diversify the economy, to build modern infrastructures, including a market, is set.

As shown in the analysis of economic situation and development in the Arab countries at the current stage, all of them have an objective need to change the structure of their economy and diversify the national economy in order to reduce dependence from mining industries, world prices fluctuations and, as a result, to reduce the vulnerability from the global economy. The main goal of these reforms is to improve the efficiency of the national economy. This is possible, as the world practice shows, only through the creation of a market economy and the subsequent active cooperation among countries in the framework of GCC. Leading countries of Western Europe in the postwar period started looking for opportunities to improve efficiency in economic integration and cooperation.

We can state a staging of Arab economic policies, its differentiation by sub-region, its changes as the socio-economic evolution of society takes place. The economic policy reflects the new processes, namely the search for a way out of the difficulties and contradictions that they faced in the frame of the world economy and that they are trying to resolve on the way to the regional cooperation.

\section{Conclusion}

The proximity of challenges in the social and economic development of Arab countries provide a basis for the formulation of the following practical considerations and appropriate measures for creation of the more rational economic structure:

- diversification of budget revenues sources through expanding industrialization;

- speeding up the development of solid minerals and the creation of new industries using them;

- increasing electricity and water desalination capacity, since the lack of a mobile reserve in these areas reduces the rate of economic development;

- development of a completely new concept of privatization, taking into account the burden of the state on major companies;

- reducing the cost of large-scale military programs;

- revision of the generous social programs targeting indigenous populations.

The implementation of these measures in the countries of the region would result in:

- foreign capital attracting;

- promoting the development of the manufacturing and service sectors, especially tourism;

- providing the population with consumer goods, especially food, including national production;

- new jobs creation.

\section{References}

1. Biryukov, E. S. (2015). Mekhanizm strukturnoy perestroyki ekonomiki v stranakh Zaliva. [The mechanism of economic restructuring in the GCC states]. Aziya i Afrika segodnya [Asia and Africa today], 1(690), 38-44. (In Russ.)

2. Shkvarya, L. V. (2015). Preobrazovaniya v arabskikh stranakh SSAGPZ i nekotoryye ikh rezultaty v XXI veke [Transformations in the Arab countries of the GCC and some of their results in the XXI century]. Upravlenie ekonomicheskimi sistemami: elektronnyy nauchnyy zhurnal [Management of Economic Systems. Scientific Electronic Journal], 7(79), 9. (In Russ.)

3. Aidrous, I. A .Z. (2015). Razvitie mezhdunarodnogo sotrudnichestva Bakhreyna v neftegazovoy sfere i rol vneshnego faktora [Development of international cooperation of Bahrain in oil and gas sector and the role of external factors]. Nauchnoye obozrenie. Seriya 1: Ekonomika i pravo [Scientific Review. Series 1: Economics and Law], 5, 5-15. (In Russ.)

4. Shkvarya, L. V. (2010). Rossiysko-arabskoye sotrudnichestvo: formirovanie vzaimnykh interesov [The Russian-Arab cooperation: mutual interests formation]. Rossiya i musulmanskiy mir [Russia and the Muslem world], 8, 120-131. (In Russ.)

5. Barakhimi, A. Kh. (1998). Hajm wa afaq altakamul aliqtisady. [The scope and prospects of Arab economic integration]. Abu Dhabi: The Centre for Strategic Studies, 58 (origin in Arabic).

6. Heikhal, A. A. (2006). Alutur alnathariya liltakatulat aliqtisadiya. [Theoretical framework economic groups]. Beirut: The Arab thought Found, 46 (origin in Arabic).

7. Balassa, B. (1962). The Theory of Economic Integration. Howewood, Illinous: Routledge, Taylor \& Francis Group, 304

8. Khalid, S. A. (2015). GCC's Economic Cooperation and Integration: Achievements and Hurdles. Mecca: AlJazeera Centre for Studies, 52.

9. Aidrus, I. A. Z. (2014). Razvitie islamskikh finansov: rol korolevstva Bahreyn [Islamic finance development: a role of the Kingdom of Bahrain]. Finansy i kredit [Finance and Credit], 47(623), 39-47. (In Russ.)

10. Isaev, M. N. (2013). Innovatsionnoye razvitie stran Persidskogo Zaliva: sovremennoye polozhenie [Innovative development of the Persian gulf: current situation]. Gornyy informatsionno-analiticheskiy byulleten [Mining informational and analytical bulletin], 12, 327-332. (In Russ.)

11. Cherif, R. (2014). Soaring of the Gulf Falcons: Diversification in the GCC Oil Exporters in Seven Propositions. Working Paper, 14 (177), International Monetary Fund, Washington. 
12. Rusakovich, V. I. (2015). Dinamika i struktura vneshney torgovli stran Zaliva: osnovnyye trendy v XXI veke [Dynamics and structure of foreign trade of the Gulf countries: the main trends in the XXI century]. Upravlenie ehkonomicheskimi sistemami: ehlektronnyy nauchnyy zhurnal [Economic systems management: an electronic scientific journal], 7(79), 8. (In Russ.)

13. Rusakovich, V. I. (2009). Investitsionnyy klimat arabskikh stran [Investment regimes in the Arab countries]. Gornyy informatsionno-analiticheskiy byulleten (nauchno-tekhnicheskiy zhurnal) [Mining informational and analytical bulletin], 9, 382-387. (In Russ.)

14. Rusakovich, V. I. (2014). Sotsialno-ekonomicheskie protsessy v stranakh Zaliva i rol zanyatosti [Socio-economic processes in the Gulf and the role of employment]. Gornyy informatsionno-analiticheskiy byulleten (nauchno-tekhnicheskiy zhurnal) [Mining informational and analytical bulletin], 2, 244-248. (In Russ.)

15. Rusakovich, V. I. (2009). Vozmozhnosti i napravleniya uchastiya stran Persidskogo zaliva v mirovykh protsessakh migratsii kapitala [Opportunities and directions of Persian gulf's countries in the global processes of capital migration]. Vestnik Rossiyskogo universiteta druzhby narodov. Seriya Ekonomika [Journal of Peoples' Friendship University of Russia. Economy Series], 3, 27-36. (In Russ.)

16. Hvidt, M. (2013). Economic Diversification in GCC Countries: Past Record and Future Trends. Research Paper 27. Kuwait Programme on Development, Governance and Globalisation in the Gulf States, London School of Economics and Political Science, London, 145.

17. Melkumyan, E. S. (1999). SSAGPZ v globalnykh i regionalnykh protsessakh [GCC in global and regional processes]. Moscow: Institute for the Study of Israel and the Middle East. Institute of oriental studies. Russian Academy of Science, 197. (In Russ.)

18. George, T. A. \& Hamid, R. D. (2003). Challenges of Growth and Globalization in the Middle East and North Africa. International Monetary Fund. Retrieved from: http://www.imf.org/external/pubs/ft/med/2003/eng/abed.htm (date of access: 16.12.2016).

19. Kravchuk, V. I. \& Rusakovich, V. I. (2014). Svobodnyye ehkonomicheskie zony v OAEH kak instrument zashchity natsionalnykh interesov [Free economic zones in the UAE as national interests protection tool]. Mirovaya ekonomika $v$ usloviyakh "upravlyaemogo haosa" i pozitsii Rossii [World economy in condition of "controlled chaos" and the position of Russia]. Moscow: Econ-Inform Publ., 205. (In Russ.)

20. Solovieva, U. V. (2015). Formirovanie i razvitie sistemy transfera tekhnologiy v Rossii i za rubezhom [Formation and development of technology transfer system in Russia and abroad]. Voprosy ekonomiki [Economics Issues], 4, 131-141. (In Russ.)

21. Solovieva, U. V. (2014). Organizatsionnyye osobennosti transfera tekhnologiy: zarubezhnyy opyt [Organizational Aspects of Technology Transfer: Foreign Experience]. Vestnik Rossiyskogo universiteta druzhby narodov. Seriya Ekonomika [Journal of Peoples' Friendship University of Russia. Economy Series], 3, 136-146. (In Russ.)

\section{Authors}

Lyudmila Vasilievna Shkvarya - Doctor of Economics, Professor, Department of Political Economics, Peoples' Friendship University of Russia (6, Miklukho-Maklaya St., Moscow, 117198, Russian Federation; e-mail: destard@rambler.ru).

Elena Dmitrievna Frolova - Doctor of Economics, Professor, Department of International Economics, Ural Federal University (19, Mira St., Ekaterinburg, 620002, Russian Federation; e-mail: frol-uved@yandex.ru). 